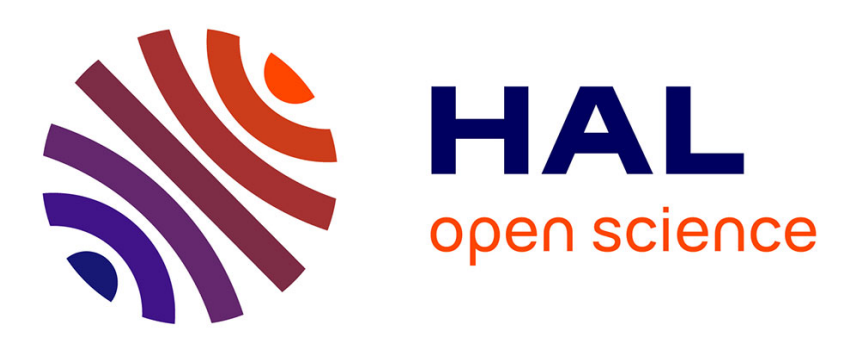

\title{
A Metal-Directed Self-Assembled Electroactive Cage with Bis(pyrrolo)tetrathiafulvalene (BPTTF) Side Walls
}

Sébastien Bivaud, Jean-Yves Balandier, Marcos Chas, Magali Allain, Sébastien Goeb, Marc Sallé

\section{- To cite this version:}

Sébastien Bivaud, Jean-Yves Balandier, Marcos Chas, Magali Allain, Sébastien Goeb, et al.. A MetalDirected Self-Assembled Electroactive Cage with Bis(pyrrolo)tetrathiafulvalene (BPTTF) Side Walls. Journal of the American Chemical Society, 2012, 134 (29), pp.11968-11970. 10.1021/ja305451v . hal-03344628

\author{
HAL Id: hal-03344628 \\ https://univ-angers.hal.science/hal-03344628
}

Submitted on 15 Sep 2021

HAL is a multi-disciplinary open access archive for the deposit and dissemination of scientific research documents, whether they are published or not. The documents may come from teaching and research institutions in France or abroad, or from public or private research centers.
L'archive ouverte pluridisciplinaire HAL, est destinée au dépôt et à la diffusion de documents scientifiques de niveau recherche, publiés ou non, émanant des établissements d'enseignement et de recherche français ou étrangers, des laboratoires publics ou privés. 


\title{
A Metal-Directed Self-Assembled Electroactive Cage with Bis(pyrrolo)tetrathiafulvalene (BPTTF) Side Walls
}

\author{
Sébastien Bivaud, Jean-Yves Balandier, Marcos Chas, Magali Allain, Sébastien Goeb, and Marc Sallé* \\ LUNAM Université, Université d'Angers, CNRS UMR 6200, Laboratoire MOLTECH-Anjou, 2 bd Lavoisier, 49045 Angers Cedex, \\ France
}

Supporting Information

ABSTRACT: A straightforward synthesis of a bis(pyrrolo)tetrathiafulvalene (BPTTF)-based tetratopic ligand bearing four pyridyl units is described. The first example of a TTF-based self-assembled cage has been produced from this redox-active ligand through metaldirected synthesis with a cis-coordinated square-planar $\mathrm{Pt}(\mathrm{II})$ complex. The resulting cage corresponds to a trigonal-prismatic structure, as shown by X-ray crystallography. A UV-vis titration indicated that the electron-rich cavity can be used to incorporate one molecule of tetrafluorotetracyano- $p$-quinodimethane $\left(\mathrm{TCNQF}_{4}\right)$.

$\mathrm{C}$ oordination-driven self-assembly has proven to be a very efficient strategy to reach host structures of various shapes and sizes, such as polygons and polyhedra, that are otherwise very challenging to reach through usual covalent chemistry. ${ }^{1}$ In addition, this methodology potentially allows one to tune the binding properties of the corresponding cavity by incorporating specific functionalities within the framework structure. Within this field, there are very few examples of self-assembled threedimensional (3D) cages involving redox-active side walls, ${ }^{2}$ and the majority of those reported incorporate electron-acceptor ligands (typically of the 1,3,5-triazine or quinone family). ${ }^{2,3}$ To the best of our knowledge, functional metallo-supramolecular cages built from highly $\pi$-electron-donating side walls are unknown to date and would constitute a fascinating system that is complementary to previous supramolecular cages made from $\pi$-electron-accepting ligands. On the other hand, the $\pi$-donating ability of tetrathiafulvalene (TTF) derivatives is wellestablished, projecting this unit as a key redox building block in various molecular and supramolecular switchable systems. ${ }^{4}$ In particular, TTF derivatives are very easily oxidized through two reversible one-electron steps. In the course of our studies related to the design of new electron-rich cavities, we recently investigated the preparation of polygons incorporating the TTF derivative bis(pyrrolo)tetrathiafulvalene (BPTTF). ${ }^{5}$ Extension of this work to a 3D level (i.e., self-assembled cages) is of striking importance in the design of cavities with addressable binding properties.

With this objective in mind, the tetrapyridyl-BPTTF ligand 3 (Scheme 1) was designed and synthesized through nucleophilic addition onto pyridine by a non-organometallic process. The reaction of BPTTF $1^{6}$ with activated triflated pyridine ${ }^{7}$ generated in situ produced compound $\mathbf{2}$ in good yield, considering that four covalent bonds are formed concomitantly
Scheme 1. Synthesis of Ligand $3^{a}$

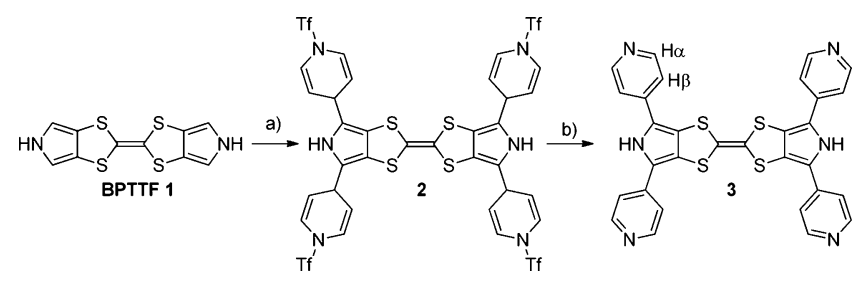

${ }^{a}$ Conditions: (a) pyridine ( 8 equiv), triflic anhydride (6 equiv), $\mathrm{CH}_{2} \mathrm{Cl}_{2},-30{ }^{\circ} \mathrm{C}, 15 \mathrm{~min}, 46 \%$; (b) tBuOK (10 equiv), THF, 45 min, $81 \%$.

( $46 \%$ yield after purification by $\mathrm{SiO}_{2}$ column chromatography). Conversion to the target tetratopic ligand 3 in $81 \%$ yield was then carried out with 10 equiv of $\mathrm{tBuOK}$ in tetrahydrofuran (THF).

The tetrapyridyl-BPTTF ligand 3 was then engaged in a selfassembly process with the cis- $\left(\mathrm{PEt}_{3}\right)_{2} \mathrm{Pt}(\mathrm{OTf})_{2}$ complex. Several discrete architectures would potentially be expected from this reaction, depending on the number of ligating units (i.e., 3) involved in the construction of the self-assembled product and/ or on their respective orientation. ${ }^{8}$ Remarkably, the reaction of 3 with a 2-fold ratio of the $\mathrm{Pt}$ (II) complex in dimethyl sulfoxide (DMSO) at $75{ }^{\circ} \mathrm{C}$ converged within $2 \mathrm{~h}$ (as determined by ${ }^{1} \mathrm{H}$ NMR monitoring), affording a single structure that was isolated by evaporation of the solvent. In particular, the corresponding spectrum condensed rapidly to a simple set of signals, as expected for a highly symmetrical structure (Figure 1). It is noteworthy that the $\alpha$ and $\beta$ proton signals of the pyridyl units were strongly modified in comparison with those of the starting ligand 3. Indeed, in addition to a significant shift due to the nitrogen-Pt(II) coordination, splitting of both pyridyl signals was observed upon self-assembly (Figure 1b), indicating that the two ${ }^{1} \mathrm{H}_{\alpha}$ protons as well as the two ${ }^{1} \mathrm{H}_{\beta}$ protons exist in magnetically different environments in the resulting complex. This observation is assigned to the restricted rotation around the $\mathrm{Pt}-\mathrm{N}$ bond because of steric constraints and suitably correlates to the case of the prismatic ${ }^{8 a}$ structure 4 (Scheme 2). The $\mathrm{NH}$ singlet was also shifted significantly downfield in the complex (+0.18 ppm), and both the ${ }^{31} \mathrm{P}$ and ${ }^{19} \mathrm{~F}$ NMR spectra exhibited a single signal, in accordance with the formation of only one species. Finally, a ${ }^{1} \mathrm{H}$ diffusion-ordered spectroscopy (DOSY) NMR experiment showed only one alignment of

Received: June 10, 2012

Published: July 6, 2012 


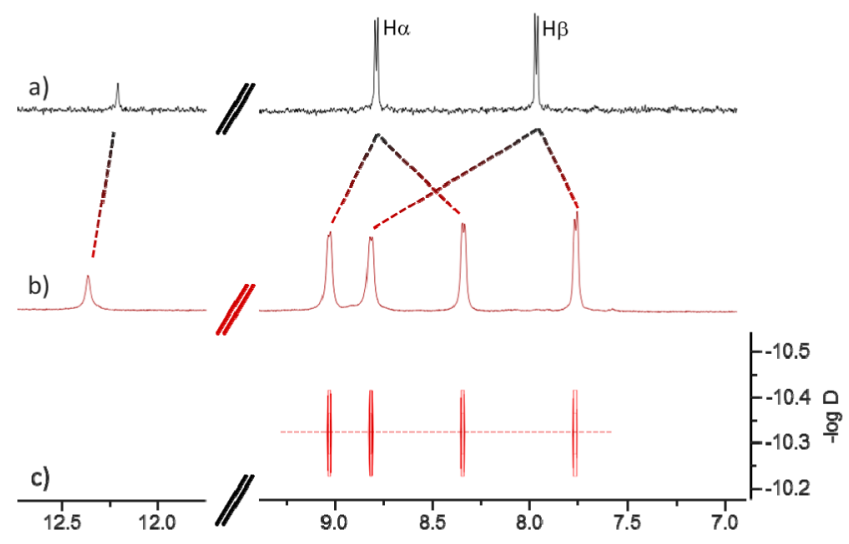

Figure 1. Downfield region (solvent DMSO- $d_{6}$ ): (a) ${ }^{1} \mathrm{H}$ NMR spectrum of 3; (b) ${ }^{1} \mathrm{H}$ NMR spectrum of 4; (c) DOSY NMR spectrum of 4 .

Scheme 2. Synthesis of the Trigonal Prism $4^{a}$

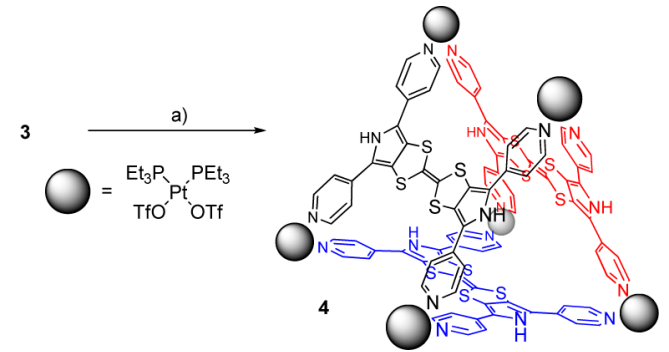

${ }^{a}$ Conditions: (a) cis-(PEt $)_{3} \mathrm{Pt}(\mathrm{OTf})_{2}$, DMSO, $75^{\circ} \mathrm{C}, 2 \mathrm{~h}$, quant.

signals (Figure 1c), confirming the presence of a single discrete self-assembled system.

Peaks attributed to the consecutive loss of triflate counterions $\left([\mathrm{M}-6 \mathrm{OTf}]^{6+}, \mathrm{m} / z\right.$ 875.6; $[\mathrm{M}-7 \mathrm{TfO}]^{5+}, \mathrm{m} / z$ 1080.7; $[\mathrm{M}-$ $8 \mathrm{TfO}]^{4+}, \mathrm{m} / z$ 1388.4) were observed by electrospray ionization mass spectrometry, confirming the transfer of the trigonalprismatic self-assembled structure $4(\mathrm{M})$ into the gas phase. Experimental isotopic patterns centered on these $m / z$ values suitably correlated with the theoretical isotopic distributions calculated for hexa-, penta-, and tetracharged species (Figure S12 in the Supporting Information).

Single crystals of the self-assembled discrete structure were grown by slow diffusion of diethyl ether in acetonitrile. X-ray diffraction experiments revealed the formation of the trigonalprismatic cage 4 (Figure 2). Very few examples of X-ray structures of self-assembled prismatic cages are available in the literature, ${ }^{9}$ and moreover, complex 4 corresponds to the first case of a TTF cage crystal structure. It is noteworthy that the
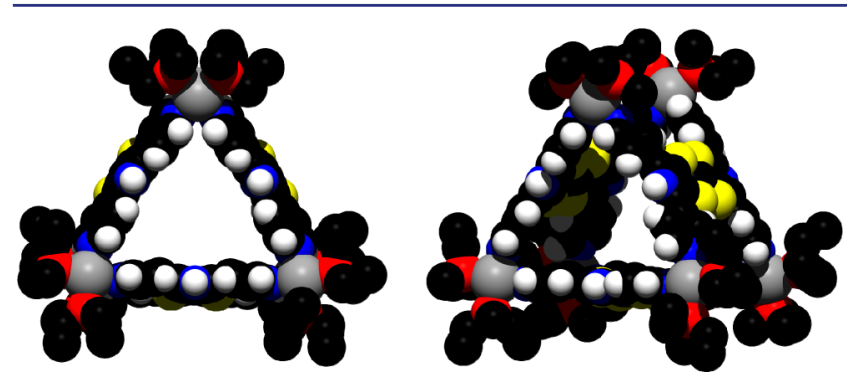

Figure 2. X-ray crystal structure of cage 4. Anions and $\mathrm{H}$ atoms of ethyl groups have been omitted. four pyridyl units on each ligand belong approximately to the same plane as the corresponding BPTTF framework, resulting in an extension of the $\pi$ conjugation through the pyridyl units. The distances between neighboring $\mathrm{Pt}$ atoms along the two directions of the cavity range from 12.6 to $14.2 \AA$, resulting in a roughly regular trigonal-prismatic cavity.

Cyclic voltammetry of cage $\mathbf{4}$ was carried out in acetonitrile containing 0.1 M NBu $\mathrm{PF}_{6}$. As shown in Figure 3, two

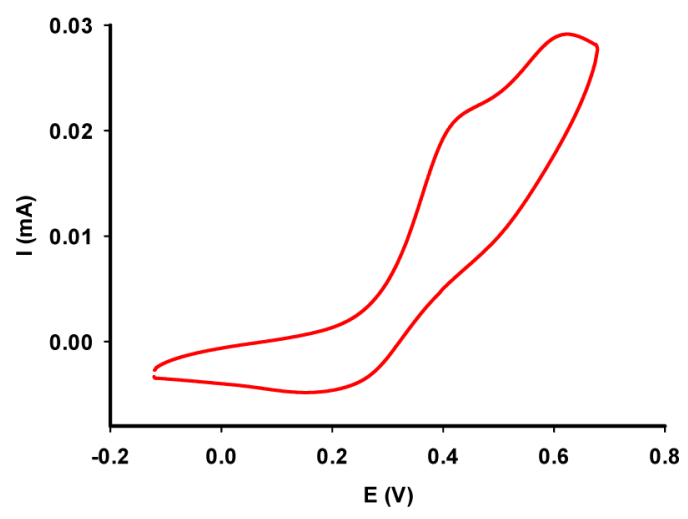

Figure 3. Cyclic voltammogram of cage $4\left[C=6 \times 10^{-4} \mathrm{M}\right.$ in acetonitrile containing $0.1 \mathrm{M} \mathrm{NBu}_{4} \mathrm{PF}_{6}$; scan rate $50 \mathrm{mV} \cdot \mathrm{s}^{-1} ; \mathrm{V}$ vs $\mathrm{Fc}$ / $\mathrm{Fc}^{+}$; working electrode (GCE)].

successive oxidation processes were observed, and cage 4 presents good $\pi$-donating character. Both redox steps $\left(E_{1}^{\text {ox }}=\right.$ $\left.0.43 \mathrm{~V} ; E_{2}^{\text {ox }}=0.62 \mathrm{~V}\right)$ are shifted to higher potentials relative to BPTTF $1\left(E_{1}^{\text {ox }}=-0.02 \mathrm{~V} ; E_{2}^{\text {ox }}=0.23 \mathrm{~V} \text {; Figure } S 13\right)^{10}$ and exhibit poor electrochemical reversibility. This observation is ascribed to a combination of electronic and structural features: (i) as shown by the X-ray structure, the through-bond communication to the metal centers via the pyridyl units and the accumulation of metal cations on the periphery of the redox BPTTF backbone contribute to a decrease in the $\pi$-electrondonating ability of 4 relative to BPTTF itself; ${ }^{11}$ and (ii) the rigidity of the $3 \mathrm{D}$ architecture contributes to a change in the kinetics of electron transfer during the electrochemical processes.

The binding ability of cage 4 was evaluated by a UV-vis titration with tetrafluorotetracyano- $p$-quinodimethane $\left(\mathrm{TCNQF}_{4}\right)$ in acetonitrile. This compound is a prototypical electron-poor guest that is prone to interact with an electrondonating cavity and (compared to TCNQ) is soluble in a wide range of solvents. Moreover, it presents a suitable size and geometry for inclusion within cage 4 . Adding aliquots of $\mathrm{TCNQF}_{4}$ to an acetonitrile solution of the electron-donating receptor led to a progressive color change, assignable to the formation of a charge-transfer complex. New absorption bands appeared (Figure 4) at 752 and $849 \mathrm{~nm}$, corresponding to the progressive formation of the $\mathrm{TCNQF}_{4}$ radical anion, ${ }^{12}$ and at $690 \mathrm{~nm}$, corresponding to the BPTTF radical cation. ${ }^{13}$ In addition, careful examination of the absorption spectra between 0 and 1 equiv (Figure S14) and 0 and 10 equiv (Figure 4) of added $\mathrm{TCNQF}_{4}$ showed the disappearance of the free receptor $4(442 \mathrm{~nm})$ with the concomitant evolution of a new band at $408 \mathrm{~nm}$, accompanied by an isosbestic point. This observation indicates that only two species are in equilibrium, as expected for a 1:1 host-guest complex, and regarding the symmetrical character of the prismatic cavity, corroborates inclusion of the $\mathrm{TCNQF}_{4}$ unit within the cavity. This statement was further 


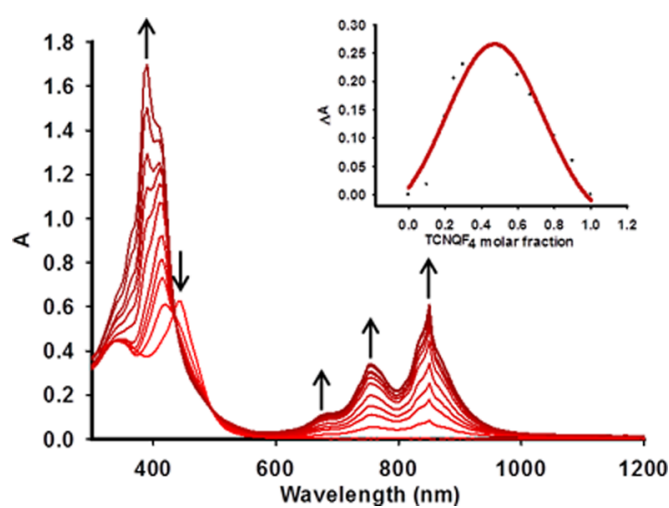

Figure 4. UV-vis titration of cage $4\left(C=6 \times 10^{-6} \mathrm{M}\right.$ in acetonitrile) with $0-10$ equiv of $\mathrm{TCNQF}_{4}\left(\mathrm{C}=1.5 \times 10^{-3} \mathrm{M}\right.$ in acetonitrile $)$. Inset: Job plot at $442 \mathrm{~nm}$ for cage $4 \mathrm{vs} \mathrm{TCNQF}_{4}$ at room temperature $\left(C=6 \times 10^{-6} \mathrm{M}\right.$ in acetonitrile $)$.

confirmed by construction of the corresponding Job plot (Figure 4 inset), which shows 1:1 stoichiometry for the complexation between 4 and $\mathrm{TCNQF}_{4}$.

An original and straightforward functionalization of BPTTF produces the tetratopic ligand 3 , which gives rise to 4 , the first example of a 3D cage incorporating the electron-rich TTF framework. The latter is a fascinating and successful framework for binding an electron-accepting $\mathrm{TCNQF}_{4}$ unit. This result opens promising perspectives as a complementary approach to the well-established use of electron-poor self-assembled receptors.

\section{ASSOCIATED CONTENT}

\section{(S) Supporting Information}

Detailed synthesis protocols, experimental methods, and additional spectroscopic data for ligand 3 and complex 4; binding studies; and details of the X-ray diffraction study of 4 . This material is available free of charge via the Internet at http://pubs.acs.org.

\section{AUTHOR INFORMATION}

\section{Corresponding Author}

marc.salle@univ-angers.fr

\section{Notes}

The authors declare no competing financial interest.

\section{ACKNOWLEDGMENTS}

This work is dedicated to the memory of Dr. Nuria GallagoPlanas. The authors gratefully acknowledge the CNRS and the Région des Pays de la Loire for a Ph.D. grant (S.B.), ANRPNANO (ANR-07-NANO-030-01) for financial support, and the platforms PIAM (Univ. Angers) and CRMPO (Univ. Rennes 1) for their assistance in spectroscopic analyses.

\section{REFERENCES}

(1) For recent reviews, see: (a) Amouri, H.; Desmarets, C.; Moussa, J. Chem. Rev. 2012, 112, 2015. (b) Chakrabarty, R.; Mukherjee, P. S.; Stang, P. J. Chem. Rev. 2011, 111, 6810. (c) Inokuma, Y.; Kawano, M.; Fujita, M. Nat. Chem. 2011, 3, 349. (d) Jin, P.; Dalgarno, S. J.; Atwood, J. L. Coord. Chem. Rev. 2010, 254, 1760. (e) Therrien, B. Eur. J. Inorg. Chem. 2009, 2445. (f) Northrop, B. H.; Zheng, Y. R.; Chi, K. W.; Stang, P. J. Acc. Chem. Res. 2009, 42, 1554. (g) Stang, P. J. J. Org. Chem. 2009, 74, 2. (h) Yoshizawa, M.; Klosterman, J. K.; Fujita, M. Angew. Chem., Int. Ed. 2009, 48, 3418. (i) Han, Y.-F.; Jia, W.-G.; Yu, W.-B.; Jin, G.-X. Chem. Soc. Rev. 2009, 38, 3419. (j) Northrop, B. H.;
Chercka, D.; Stang, P. J. Tetrahedron 2008, 64, 11495. (k) Northrop, B. H.; Yang, H. B.; Stang, P. J. Chem. Commun. 2008, 5896. (1) Cooke, M. W.; Chartrand, D.; Hanan, G. S. Coord. Chem. Rev. 2008, 252, 903. (m) Dalgarno, S. J.; Power, N. P.; Atwood, J. L. Coord. Chem. Rev. 2008, 252, 825. (n) Zangrando, E.; Casanova, M.; Alessio, E. Chem. Rev. 2008, 108, 4979. (o) MacGillivray, L. R. Angew. Chem., Int. Ed. 2012, 51, 1110. (p) De, S.; Mahata, K.; Schmittel, M. Chem. Soc. Rev. 2010, 35, 1555.

(2) Amijs, C. H. M.; van Klink, G. P. M.; van Koten, G. Dalton Trans. 2006, 308.

(3) (a) Bhattacharya, D.; Chang, C.-H.; Cheng, Y.-H.; Lai, L.-L.; Lu, H.-Y.; Lin, C.-Y.; Lu, K.-L. Chem.-Eur. J. 2012, 18, 5275. (b) Mattsson, J.; Govindaswamy, P.; Renfrew, A. K.; Dyson, P. J.; Stepnicka, P.; Süss-Fink, G.; Therrien, B. Organometallics 2009, 28, 4350.

(4) For reviews, see: (a) Canevet, D.; Sallé, M.; Zhang, G.; Zhang, D.; Zhu, D. Chem. Commun. 2009, 2245. (b) Martín, N.; Segura, J.-L. Angew. Chem., Int. Ed. 2001, 40, 1372. (c) Bryce, M. R. J. Mater. Chem. 2000, 10, 589. (d) Nielsen, M. B.; Lomholt, C.; Becher, J. Chem. Soc. Rev. 2000, 29, 153.

(5) (a) Goeb, S.; Bivaud, S.; Dron, P. I.; Balandier, J.-Y.; Chas, M.; Sallé, M. Chem. Commun. 2012, 48, 3106. (b) Balandier, J.-Y.; Chas, M.; Goeb, S.; Dron, P. I.; Rondeau, D.; Belyasmine, A.; Gallego, N.; Sallé, M. New J. Chem. 2011, 35, 165.

(6) (a) Balandier, J.-Y.; Chas, M.; Dron, P. I.; Goeb, S.; Canevet, D.; Belyasmine, A.; Allain, M.; Sallé, M. J. Org. Chem. 2010, 75, 1589.

(b) Balandier, J.-Y.; Belyasmine, A.; Sallé, M. Synthesis 2006, 2815.

(7) Corey, E. J.; Tian, Y. Org. Lett. 2005, 7, 5535.

(8) (a) Caskey, D. C.; Yamamoto, T.; Addicott, C.; Shoemaker, R. K.; Vacek, J.; Hawkridge, A. M.; Muddiman, D. C.; Kottas, G. S.; Michl, J.; Stang, P. J. J. Am. Chem. Soc. 2008, 130, 7620. (b) Yamanoi, Y.; Sakamoto, Y.; Kusukawa, T.; Fujita, M.; Sakamoto, S.; Yamagushi, K. J. Am. Chem. Soc. 2001, 123, 980.

(9) (a) Stephenson, A.; Argent, S. P.; Riis-Johannessen, T.; Tidmarsh, I. S.; Ward, M. D. J. Am. Chem. Soc. 2010, 133, 858. (b) Fujita, N.; Biradha, K.; Fujita, M.; Sakamoto, S.; Yamaguchi, K. Angew. Chem., Int. Ed. 2001, 40, 1718.

(10) The cyclic voltammogram of the precursor ligand 3 could not be recorded under these conditions because of a lack of solubility.

(11) Beer, P. D.; Gale, P. A.; Chen, G. Z. Coord. Chem. Rev. 1999, $185,3$.

(12) Jain, A.; Rao, K. V.; Mogera, U.; Sagade, A. A.; George, S. J. Chem.-Eur. J. 2011, 17, 12355.

(13) Nygaard, S.; Laursen, B. W.; Hansen, T. S.; Bond, A. D.; Flood, A. H.; Jeppesen, J. O. Angew. Chem. 2007, 119, 6205. 